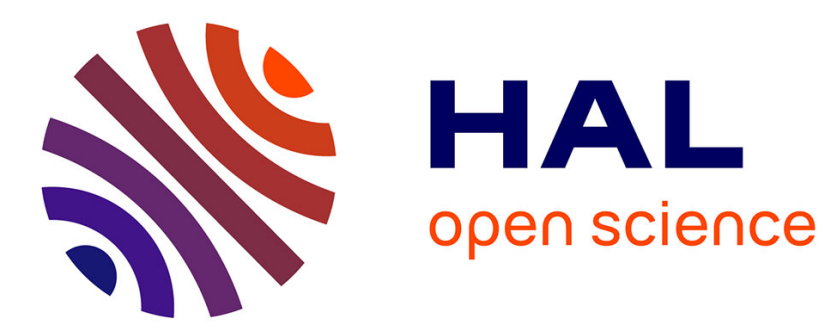

\title{
Biomonitoring of Pt and Pd with Mosses
}

Sophie Ayrault, Chunsheng Li, André Gaudry

\section{To cite this version:}

Sophie Ayrault, Chunsheng Li, André Gaudry. Biomonitoring of Pt and Pd with Mosses. Fathi Zereini; Friedrich Alt. Palladium Emissions in the Environment: Analytical Methods, Environmental Assessment and Health Effects, Springer-Verlag, pp.525-536, 2006, 978-3-540-29220-3 (Online). 10.1007/3-540-29220-9_34. cea-02640040

\section{HAL Id: cea-02640040 https: / hal-cea.archives-ouvertes.fr/cea-02640040}

Submitted on 29 May 2020

HAL is a multi-disciplinary open access archive for the deposit and dissemination of scientific research documents, whether they are published or not. The documents may come from teaching and research institutions in France or abroad, or from public or private research centers.
L'archive ouverte pluridisciplinaire HAL, est destinée au dépôt et à la diffusion de documents scientifiques de niveau recherche, publiés ou non, émanant des établissements d'enseignement et de recherche français ou étrangers, des laboratoires publics ou privés. 


\title{
1 Biomonitoring of Pt and Pd with mosses
}

\author{
Sophie Ayrault ${ }^{1,2^{*}}$, Chunsheng $\mathrm{Li}^{1,3}$, André Gaudry ${ }^{1}$ \\ ${ }^{1}$ Laboratoire Pierre Süe, CEA/CNRS, CEA Saclay, F-91191 Gif-sur- \\ Yvette Cedex, France \\ 2 Current address: Laboratoire des Sciences du Climat et de \\ l'Environnement, CNRS-CEA, 12 avenue de la terrasse, F-91198 Gif-sur- \\ Yvette cedex, France \\ ${ }^{3}$ Current address: Radiation Protection Bureau, Health Canada, 775 \\ Brookfield Road, Ottawa, ON, Canada K1A 1C1 \\ * Correspondence author. Tel.: +33-1-69-82-43-54; fax: +33-1-69-82-35- \\ 68. E-mail address: sophie.ayrault@1sce.cnrs-gif.fr
}

\subsection{Introduction}

Platinum $(\mathrm{Pt})$, palladium $(\mathrm{Pd})$, and rhodium $(\mathrm{Rh})$ belong to the rarest element group in the lithosphere and biosphere. Their background values lie in the range of $0.1 \mathrm{ng} \cdot \mathrm{g}^{-1}$ to $1 \mathrm{ng} \cdot \mathrm{g}^{-1}$ (Wedepohl, 1995). However, since the introduction of Pt-containing auto catalyst converters during the 1970's in the USA and later in Japan and Europe, their concentrations in the environment, especially in the roadside environment, have increased rapidly (Lustig, 1997). Retrospective studies on airborne dust samples (Zereini et al. 1997) and ancient ice (Barbante et al. 2001) have facilitated the assessment of the environmental dispersion of these platinum group elements (PGE). Increases in the concentration of PGEs in the environment have been documented in numerous countries and matrixes (Ravindra et al. 2004).

As a result, there is now a growing concern on the ecological and human risk of increasing concentrations of PGE in the environment. There have been several passive biomonitoring studies to investigate the bioaccumula- 
tion of platinum in animals and plants. An experiment of active biomonitoring of platinum has been performed using grass cultures (Dietl et al. 2000). Palladium bioaccumulation has been less documented as stated by Lustig and Schramel (2000).

Moss analyses have been utilized successfully in the environmental biomonitoring of heavy metal atmospheric deposition studies during the past 30 years (e.g. Steinnes, 1995). Both active (using transplanted moss) and passive (using endogenous) monitoring methods have been developed and applied to the monitoring of inorganic and organic pollutants. The following sections examine the feasibility of using mosses to assess Pt and Pd pollution in the region of Paris, France, and compare the obtained data with those published on PGE biomonitoring using grass.

\subsection{Literature overview.}

Sine the increase of the PGE concentrations was recognized in the environment by pioneer German studies, there has been an intense discussion on the levels of these elements in the environment, their pathway from dust to plants and their ecotoxicology.

After several years of development and improvement of analytical methods, PGE levels were measured in a wide range of plant species and sites. Table 1 summarizes the literature data for PGE concentrations in grass and moss. Additional data for plants can be found in Ravindra et al. (2004). 
Table 1. Literature overview: concentrations of Pt, Rh and Pd in grass and moss ( $\mu \mathrm{g} \cdot \mathrm{kg}^{-1}$ of dry weight).

\begin{tabular}{|c|c|c|c|c|c|c|c|c|c|}
\hline Sample & Year & Sampling site & $\begin{array}{l}\text { Distance from } \\
\text { road }(\mathrm{m})\end{array}$ & $\mathrm{Pt}$ & $\mathrm{Rh}$ & $\mathrm{Pd}$ & $\mathrm{Pt} / \mathrm{Rh}$ & $\mathrm{Pt} / \mathrm{Pd}$ & Data source \\
\hline Grass & 1995 & $\begin{array}{l}\text { Highway, Ger- } \\
\text { many }\end{array}$ & & 5 & & 0.6 & & 8.3 & $\begin{array}{l}\text { Schäfer et al. } \\
1998\end{array}$ \\
\hline Washed $^{\mathrm{a}}$ grass & & $\begin{array}{l}\text { Indiana Toll } \\
\text { road, US }\end{array}$ & 0 & $1.23 \pm 0.27$ & $0.10 \pm 0.02$ & $1.03 \pm 0.23$ & 12.3 & 1.2 & $\begin{array}{l}\text { Ely et al. } \\
2001\end{array}$ \\
\hline Grass & & $\begin{array}{l}\text { Indiana Toll } \\
\text { road, US }\end{array}$ & 0 & $1.73 \pm 0.44$ & $0.11 \pm 0.04$ & $1.29 \pm 0.25$ & 15.7 & 1.3 & \\
\hline Washed $^{\mathrm{a}}$ grass & & $\begin{array}{l}\text { Indiana Toll } \\
\text { road, US }\end{array}$ & 18 & $1.69 \pm 0.19$ & $0.10 \pm 0.03$ & $0.97 \pm 0.37$ & 16.9 & 0.9 & \\
\hline Grass & & $\begin{array}{l}\text { Indiana Toll } \\
\text { road, US }\end{array}$ & 18 & $1.41 \pm 0.68$ & $0.12 \pm 0.05$ & $1.44 \pm 0.30$ & 11.8 & 1.0 & \\
\hline $\begin{array}{l}\text { Moss (Rhytidiadel- } \\
\text { phus squarrosus) }\end{array}$ & 1999 & $\begin{array}{l}\text { Saarbruecken, } \\
\text { Germany }\end{array}$ & & $30 \pm 2$ & $5.4 \pm 0.5$ & $2.4 \pm 0.3$ & 5.6 & 12.5 & $\begin{array}{l}\text { Djingova et } \\
\text { al. } 2003\end{array}$ \\
\hline $\begin{array}{l}\text { Dandelion (Tarax- } \\
\text { acum officinale) }\end{array}$ & & & & $5.4 \pm 04$ & $2.2 \pm 0.3$ & $0.83 \pm 0.15$ & 2.5 & 6.5 & \\
\hline $\begin{array}{l}\text { Plantain (Plantago } \\
\text { lanceolata) }\end{array}$ & & & & $3.6 \pm 0.5$ & $1.3 \pm 0.4$ & $0.45 \pm 0.18$ & 2.8 & 8 & \\
\hline $\begin{array}{l}\text { Mushrooms (Vas- } \\
\text { cellum pratense) }\end{array}$ & & & & $5.9 \pm 0.6$ & $0.5 \pm 0.1$ & $0.2 \pm 0.1$ & 11.8 & 29.5 & \\
\hline $\begin{array}{l}\text { Dandelion (Tarax- } \\
\text { acum officinale) }\end{array}$ & & $\begin{array}{l}\text { Highway A-1, } \\
\text { Germany }\end{array}$ & 1 & $30 \pm 1$ & $7.0 \pm 0.6$ & $3.1 \pm 0.4$ & 4.3 & 9.7 & \\
\hline $\begin{array}{l}\text { Plantain (Plantago } \\
\text { lanceolata) }\end{array}$ & & & & $10.1 \pm 0.5$ & $3.4 \pm 0.5$ & $2.1 \pm 0.2$ & 3.0 & 4.8 & \\
\hline $\begin{array}{l}\text { Ryegrass (Lolium } \\
\text { multiflorum) }\end{array}$ & & & & $4.6 \pm 0.3$ & $2.2 \pm 0.4$ & $0.10 \pm 0.03$ & 2.1 & 46 & \\
\hline Dandelion (Tarax- & & Highway A-61, & 1 & $11.5 \pm 0.8$ & $3.0 \pm 0.2$ & $1.5 \pm 0.4$ & 3.8 & 7.7 & \\
\hline
\end{tabular}


41 Biomonitoring of Pt and Pd with mosses

\begin{tabular}{|c|c|c|c|c|c|c|c|c|c|}
\hline acum officinale) & & Germany & & & & & & & \\
\hline $\begin{array}{l}\text { Ryegrass (Lolium } \\
\text { multiflorum) }\end{array}$ & & & & $5.8 \pm 0.4$ & $2.1 \pm 0.3$ & $0.10 \pm 0.03$ & 2.8 & 58 & \\
\hline $\begin{array}{l}\text { Dandelion (Tarax- } \\
\text { acum officinale) }\end{array}$ & & $\begin{array}{l}\text { Road B-262, } \\
\text { Germany }\end{array}$ & 1 & $6.4 \pm 0.5$ & $2.0 \pm 0.3$ & $0.9 \pm 0.1$ & 3.2 & 7.1 & \\
\hline $\begin{array}{l}\text { Plantain (Plantago } \\
\text { lanceolata) }\end{array}$ & & & & $4.0 \pm 0.3$ & $0.5 \pm 0.1$ & $1.1 \pm 0.2$ & 8.0 & 3.6 & \\
\hline \multirow[t]{4}{*}{$\begin{array}{l}\text { Moss (Pleurozium } \\
\text { schreberi) }\end{array}$} & 2003 & $\begin{array}{l}12500 \text { v./day } \\
\text { Oulu, Finland }\end{array}$ & 10 & $27.4 \pm 5.4$ & $4.6 \pm 0.6$ & & 6.0 & & $\begin{array}{l}\text { Niemelä et } \\
\text { al. } 2004\end{array}$ \\
\hline & & 29000 v./day & 3 & $21.9 \pm 3.4$ & $3.6 \pm 0.4$ & & 6.1 & & \\
\hline & & 29500 v./day & $12-15$ & $6.4 \pm 0.5$ & $1.2 \pm 0.1$ & & 5.3 & & \\
\hline & & 43000 v./day & 9 & $14.7 \pm 3.5$ & $3.7 \pm 0.2$ & & 4.0 & & \\
\hline $\begin{array}{l}\text { Dandelion (Tarax- } \\
\text { acum vulgare) }\end{array}$ & & 43000 v./day & 2 & $1.2 \pm 0.3$ & $<0.3$ & & $>4$ & & \\
\hline $\begin{array}{l}\text { Grass (Cala- } \\
\text { mogrosis sp.) }\end{array}$ & & & 1 & $1.7 \pm 0.3$ & $0.7 \pm 0.1$ & & 2.4 & & \\
\hline
\end{tabular}

${ }^{a}$ washed with ethanol 
The PGE concentrations in plants contaminated by road traffic are highly variable from a study to another. At least, in the same study, when the plant species and the analytical procedure are identical, and the sampling site comparable, the elemental concentration or the concentrations ratio are close (Ely et al. 2001; Vanhaecke et al. 2002). When multiple species are investigated (Alt et al. 1997; Djingova et al. 2003; Niemelä et al. 2004), the concentration varies in one order of magnitude. Mosses exhibit the highest PGE concentrations, while the elemental ratio observed is comparable to those observed for dandelion or plantain. The main difficulty with mosses is to sample them in open and polluted spaces very close to road. The rye grass Lolium multiflorum, easy to find along roads, appears to fairly concentrate the PGE. The highest Pt/Pd ratios are found for Lolium multiflorum because of very low Pd concentration observed for that species (Djingova et al. 2003). Djingova et al. (2003) concluded from a study of different plant species collected in the same site that the PGE accumulation behaviour of plants was similar to those of heavy metals and toxic elements. Similar accumulation trends were seen for PGE and traffic-related elements: Pb, Ce, Zr, La, Ni, Zn, Cu (Ely et al. 2001; Djingova et al. 2003; Niemelä et al. 2004).

Several authors except Ely et al. (2001) noticed the sharp decrease in PGE concentrations when sampling distance from road edge increased. As the plants are usually unwashed, the concentrations should be interpreted as a sum of material deposited on leaves and PGE incorporated. Dust deposition seems to be the main contamination source. Nevertheless, for grass (species not specified), the washing with ethanol was ineffective to change the PGE concentration (Ely et al. 2001). This is probably due to the relative low ability of grass to accumulate dust conversely to mosses. The sampling is usually done after a dry period (Helmers and Mergel, 1998; Djingova et al. 2003) because rain may reduce PGE concentration by washing leaves. The soil-to-plant transfer of Pt has been measured by several authors (Alt et al. 1997; Lustig et al. 1997; Djingova et al. 2003). The transfer of Pd from soil to plant is considered to be more effective because of higher solubility of emitted species, compared to Pt and Rh species (Schäfer et al. 1998; Amosse and Delbos, 2002). 


\subsection{Passive and active Pt and Pd biomonitoring with mosses in Paris area.}

\subsubsection{Materials and methods}

The analytical procedure used for this work is described briefly in the following. Open-air ashing was used for sample decomposition although microwave-based methods are preferred (e.g. Vanhaecke et al. 2002; Niemelä et al. 2004). Prior to ICP-MS analysis, a chemical separation was necessary to eliminate interfering elements $(\mathrm{Cu}, \mathrm{Y}$ and $\mathrm{Zr})$.

\subsubsection{Reagents.}

The stock solutions $\left(1000 \mu \mathrm{g} \cdot \mathrm{ml}^{-1}\right)$ of $\mathrm{Pt}$ and $\mathrm{Pd}$ were provided by Carlo Erba ${ }^{\circledR}$ and Spex ${ }^{\circledR}$ respectively. An internal standard solution containing 1000 ng. $\mathrm{ml}^{-1}$ In and Re was prepared by mixing single element solutions $\left(\right.$ Spin ${ }^{\circledR}$ and $\mathrm{Teknolab}{ }^{\circledR}$, respectively) in $10 \% \mathrm{HNO}_{3}$. Nitric acid (65\%) and HF $(40 \%)$ were provided by Prolabo ${ }^{\circledR}$ (Normatom quality), and $36 \%$ $\mathrm{HCl}$ by Labosi ${ }^{\circledR}$ (analytical grade). Ultra-pure water used in the experiments $\left(18.2 \mathrm{M} \Omega-\mathrm{cm}\right.$ resistance) was provided by the alfa-Q Millipore ${ }^{\circledR}$ water purification system. Both thiourea and Amberlyst A-26 were analytical grade $\left(\right.$ Carlo $\left.\operatorname{Erba}{ }^{\circledR}\right)$. The resin was received in the $\mathrm{Cl}^{-}$ionic form and has an exchange capacity of $4.4 \mathrm{mmol} . \mathrm{g}^{-1}$ and a specific surface area of $18.4 \mathrm{~m}^{2} \cdot \mathrm{g}^{-1}$. The resin was washed with water and pretreated overnight with 2 mol. $1^{-1} \mathrm{HCl}$ before being slurred to columns for loading. The PGE were measured using a quadrupole ICP-MS (VG ${ }^{\circledR}$ Plasma Quad 2+) using the scanning mode. ${ }^{115} \mathrm{In}$ and ${ }^{187} \mathrm{Re}$ were used as internal standards. Calibration was achieved using freshly prepared solutions in the range of $0.5-5$ ng. $\mathrm{ml}^{-1}$. The stability of these solutions was tested over several weeks. It was observed that Pd solutions were unstable in this concentration range, even at $4^{\circ} \mathrm{C}$. After two weeks, palladium concentrations decreased during storage and its stability was not improved by the addition of $\mathrm{Cl}^{-}$. In contrast, $\mathrm{Rh}$ and $\mathrm{Pt}$ solutions were stable over a two-month storage interval at $4^{\circ} \mathrm{C}$. 


\subsubsection{Analytical procedure.}

Ashing. All samples were cleared of coarse particles, under microscope without washing, and then dried at room temperature. Prior to analysis, the mosses were dried at $24^{\circ} \mathrm{C}$ to constant weight (approx. 24 hours). Samples were finely ground using an agate mill. Portions of the sample, about 2 to 10 grams, were transferred to a quartz beaker, subjected to a 2-step burning in an electric oven, carbonated for 3 hours at $220-230{ }^{\circ} \mathrm{C}$, and finally ashed for another 3 hours at $650-670^{\circ} \mathrm{C}$.

Digestion. The ash was transferred from the quartz beaker to a PTFE digestion bomb using $10 \mathrm{ml}$ aqua regia $\left(\mathrm{HCl}: \mathrm{HNO}_{3} 3: 1\right)$. Acid digestion lasted 3 hours at $200{ }^{\circ} \mathrm{C}$. After evaporating of the solution to near dryness and adding another $5 \mathrm{ml}$ of $40 \% \mathrm{HF}$, the digestion was repeated for another 3 hours at $200{ }^{\circ} \mathrm{C}$. The solution was evaporated again to near dryness and $\mathrm{HF}$ was eliminated by adding of $2 \mathrm{ml}$ of concentrated $\mathrm{HNO}_{3}$ and evaporating to dryness.

Separation. The residue was dissolved in $20 \mathrm{ml}$ of $1.2 \mathrm{~mol} . \mathrm{L}^{-1} \mathrm{HCl}$, and loaded from the top of the Amberlyst A-26 column (50 mm resin bed). The bomb and the column were rinsed twice using $10 \mathrm{ml}$ of $1.2 \mathrm{~mol}^{-\mathrm{L}^{-1} \mathrm{HCl}}$ at $1 \mathrm{ml} \cdot \mathrm{mn}^{-1}$. The fixation solution and the rinsing solution were discarded. The column was eluted with $20 \mathrm{ml}$ of $2.0 \%$ thiourea at a flow rate of 1 $\mathrm{ml} . \mathrm{mn}^{-1}$. All flow rates must be well controlled.

Dissolving. The eluate was collected in a $50 \mathrm{ml}$ PTFE beaker and carefully evaporated to near dryness on a hot plate. The residue was dissolved with $5 \mathrm{ml}$ of $6 \mathrm{M} \mathrm{HNO}_{3}$. The solution volume was slowly decreased by evaporation to about $0.5 \mathrm{ml}$, then transferred to a $25 \mathrm{ml} \mathrm{PE}$ measurement tube. The beaker was washed using $0.2 \mathrm{M} \mathrm{HNO}_{3}$ and the solution transferred into the tube. The volume of the final solutions was $19.8 \mathrm{ml}$. Internal standard elements were added in order to obtain a concentration of $10 \mathrm{ng} \cdot \mathrm{ml}^{-1}$. Solutions were kept at $4{ }^{\circ} \mathrm{C}$ until analysis. Storage before analysis never exceeded one week.

Chemical recoveries were tested for Pt and Pd (additions of 10 to $100 \mathrm{ng}$ of Pt and Pd to $1 \mathrm{~g}$ of dry moss) and indicated that the recovery reached 95 $\%$. The detection limit was calculated to $0.06 \mu \mathrm{g} \cdot \mathrm{kg}^{-1}$, for a 10 -g sample weight. The uncertainties were 10 and $20 \%$ for concentration of 1 and 10 $\mu \mathrm{g} . \mathrm{kg}^{-1}$ respectively. 


\subsubsection{Passive biomonitoring}

As it can be seen from literature (Djingova et al. 2003; Niemelä et al. 2004), the passive biomonitoring (use of endogenous plants) with mosses is a difficult matter because of the difficulty to find specimens very close to the road. The sampling site selected for this study was a forest, the Fontainebleau forest $50-\mathrm{km}$ south of Paris crossed by the A6-highway $(65,000$ vehicles/day). A 10-meter long area where mosses were growing was found near to the road edge. Each moss was sampled and analysed separately. The moss species were Cirriphyllum piliferum, Eurhynchium speciosum, Physcomitrium eurystomum, Pylasisia polyantha, Rhacomitrium canescens, Polytricum formosum and Scleropodium purum. The sampling distance to road edge ranged from 5 to 15 meters. Table 2 gives $\mathrm{Pt}$ and $\mathrm{Pd}$ concentrations in the 9 mosses.

Table 2. Concentrations of Pt and Pd in mosses collected near the A6 highway, located $50 \mathrm{~km}$ south of Paris in 1999 ( $\mu \mathrm{g} . \mathrm{kg}^{-1}$ of dry weight).

\begin{tabular}{lrrr}
\hline Moss species (dist. from roadside) & \multicolumn{1}{c}{$\mathrm{Pt}$} & $\mathrm{Pd}$ & $\mathrm{Pt} / \mathrm{Pd}$ \\
\hline Cirriphyllum piliferum $(5 \mathrm{~m})$ & 8.1 & 1.3 & 6.2 \\
Eurhynchium speciosum $(5 \mathrm{~m})$ & 9.1 & 0.9 & 10.1 \\
Physcomitrium eurystomum $(5 \mathrm{~m})$ & 12.0 & 3.1 & 3.9 \\
Physcomitrium eurystomum $(5 \mathrm{~m})$ & 12.0 & 2.3 & 5.2 \\
Pylasisia polyantha $(5 \mathrm{~m})$ & 5.8 & 1.8 & 3.2 \\
Rhacomitrium canescens $(5 \mathrm{~m})$ & 5.2 & 5.8 & 0.9 \\
Polytricum formosum $(10 \mathrm{~m})$ & 1.7 & $<0.5$ & \\
Eurhynchium speciosum $(10 \mathrm{~m})$ & 4.4 & $<0.6$ & \\
Scleropodium purum $(15 \mathrm{~m})$ & 2.4 & $<0.5$ & \\
\hline
\end{tabular}

Pt and Pd concentrations in mosses collected from the roadside were significantly higher than those in the unpolluted mosses, ranging from 5.2 to $12 \mu \mathrm{g} . \mathrm{kg}^{-1}$ of dry matter for Pt and 0.9 to $6 \mu \mathrm{g} \cdot \mathrm{kg}^{-1}$ for Pd. A group of samples was collected at a 5-meter distance from the highway. They display average $\mathrm{Pt}$ and $\mathrm{Pd}$ concentrations of $8.7 \pm 2.7 \mu \mathrm{g} \cdot \mathrm{kg}^{-1}$ and $2.5 \pm 1.6$ $\mu \mathrm{g} . \mathrm{kg}^{-1}$, respectively. Pt/Pd ratio ranged 0.9 to 10.1 , with an average of 4.9 \pm 2.8 . For samples from a second group of mosses taken at 10 - and $15-\mathrm{m}$ distances, the Pt average concentration was $2.8 \mu \mathrm{g} \cdot \mathrm{kg}^{-1} \pm 1.1$, while $\mathrm{Pd}$ was not detected $\left(<0.5 \mu \mathrm{g} . \mathrm{kg}^{-1}\right)$. Thus, a sharp gradient exists near the vicinity of the road, as generally observed in previous studies (e.g. Niemelä et al. 2004). Two cushions of Physcomitrium growing at the same distance from 
road side were sampled separately. The Pt content was the same for both cushions, but Pd content was different.

Comparing to literature data (Table 1), Pt concentrations obtained in this present work (Table 2) are lower, while Pd concentrations are comparable to the published results for mosses. One problem in using natural mosses for passive biomonitoring of heavy metals is that it is generally not possible to know the period when the mosses accumulate elements. This is possibly one of the reasons that may explain the different concentrations of the same element between the various species of mosses collected at the same site. Another reason could be a difference in Pt and Pd solubility in rain (Amosse and Delvos, 2002) or the capture efficiency according to species and element differences. In addition, emission heterogeneity, as shown by the heterogeneous sample-to-sample composition for roadside dust (Farago et al. 1998), may add some variation to the results. The average $\mathrm{Pt} / \mathrm{Pd}$ ratios reported for roadside dusts are highly variable (Ravindra et al. 2004). In addition, converter technology has changed over time and is not uniform in all the countries where they are used. The PGE concentrations in plants exposed to traffic pollution is the result of a number of parameters. Among them, several parameters can be listed: plant species, traffic intensity, converters technology, wind direction, distance from road, preparation procedure and analytical procedure. At this point, the comparison of data issued from different studies is questionable. Nevertheless, if only one parameter is variable when all the other are maintained constant, the comparison is valuable. It is the case for the retrospective study of one site with the same species (Helmers and Mergel, 1998) or the comparison of different species in the same site (Djingova et al. 2003; Niemelä et al. 2004).

\subsubsection{Active biomonitoring}

The advantages of active versus passive monitoring are numerous. The species, the distance from road, exposure site and duration can be chosen. The mosses have demonstrated their ability for PGE accumulation. Thus, they were chosen for this active biomonitoring test.

The mosses used for active biomonitoring experiments were sampled in the Fontainebleau forest, which is located $50 \mathrm{~km}$ south of Paris. The sampling site was located at a distance more than one kilometre from high traffic motorways and under a tree canopy. Two samples from this "unpolluted" site, so-called blank mosses, Scleropodium purum and Polytricum formosum, were analysed. Concentrations of $<0.2 \mu \mathrm{g} . \mathrm{kg}^{-1}$ and $0.6 \mu \mathrm{g} \cdot \mathrm{kg}^{-1}$ were determined for $\mathrm{Pt}$, respectively. Palladium concentrations were below 
the detection limit $\left(<0.2 \mu \mathrm{g} . \mathrm{kg}^{-1}\right)$ for both species. The moss Polytricum is most liable to soil contamination because of its morphology. Scleropodium $p$. was then retained for further experiments. Previous work in our laboratory has shown the ability of this species, also called Scleropodium purum, to be used as a biomonitoring tool for heavy metals deposition (AmblardGross et al. 2002).

Scleropodium purum was sampled in this site and the moss cushions were set in plastic trays. The mosses were acclimated to the trays in open air area near the laboratory for two days and then transported to Paris.

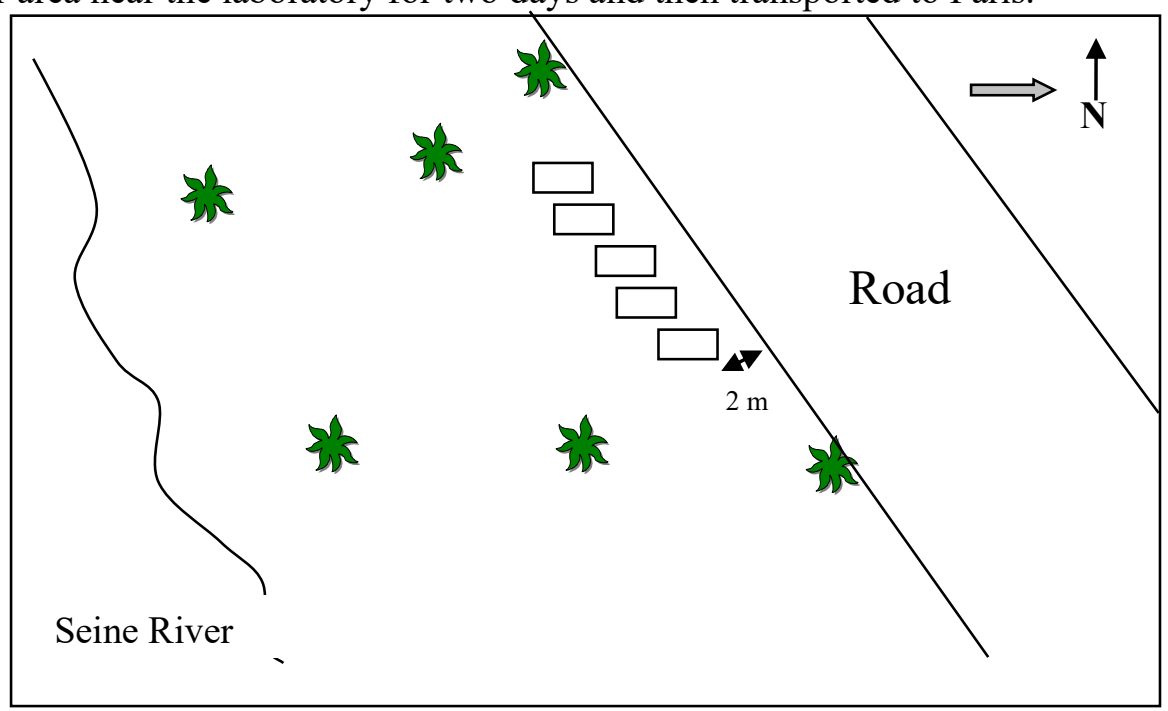

Fig. 1. The Bois de Boulogne camping is bordered by a road and the Seine River. The trays containing moss cushions were set 2 meters from the road edge, avoiding the small trees and exposed for one month. The gray arrow represents the prevailing wind direction.

The exposing site was the Bois de Boulogne camping in the west of Paris. This site is bordered by a road with very dense traffic on one side, and by the Seine River in the other side (Fig 1). This represents the typical urban driving mode (automobiles having speeds from 0 to $70 \mathrm{~km} . \mathrm{h}^{-1}$ during the night and week ends; 0 to $30 \mathrm{~km} \cdot \mathrm{h}^{-1}$ during peak-hours of work days in the morning between 7 am and 9 am and the afternoon between 5 and 7 $\mathrm{pm})$. Furthermore, trucks and buses do not use this road which tends to decrease the contribution of diesel motors to roadside pollution when compared to highway traffic. This site allows the exposure of moss transplants in an urban context. It was possible to set the mosses directly on soil in relatively safe conditions. Otherwise, biomonitors settled in busy streets 
are usually destroyed, even when put on a bus shelter top. Its main disadvantage was to not be to the windward of the prevailing wind direction.

The trays containing the moss cushions were set to $2 \mathrm{~m}$ from the road edge. Transplants of Scleropodium purum were exposed to this environment during one month on February 1999. Results from 6 sub-sample analyses are given in Table 3. Pt concentrations ranged from 1.9 to 4.3 $\mu \mathrm{g} . \mathrm{kg}^{-1}$, averaging $3.1 \pm 0.9 \mu \mathrm{g} . \mathrm{kg}^{-1}$ of dry moss. Pd concentrations ranged from $0.7 \mu \mathrm{g} . \mathrm{kg}^{-1}$ to 2.5 , averaging $1.3 \pm 0.7 \mu \mathrm{g} . \mathrm{kg}^{-1}$. The $\mathrm{Pt} / \mathrm{Pd}$ ratios range from 1.7 to 4.8 , averaging $2.8 \pm 1.1$. The variability observed was less than that for the passive biomonitoring. This is expected as the use of only one moss species means the bioavailability of Pt and Pd remains constant (provided that the chemical form of the element remains the same). The Pt concentrations measured in these mosses were rather low compared to literature. This could be due to the shortness of the experiment, and to the site characteristics (not under prevailing wind direction).

Table 3. $\mathrm{Pt}$ and $\mathrm{Pd}$ concentration ( $\mu \mathrm{g} \cdot \mathrm{kg}^{-1}$ dry weight) in Scleropodium purum, exposed for one month to an urban area west of Paris.

\begin{tabular}{rccc}
\hline & $\mathrm{Pt}$ & $\mathrm{Pd}$ & $\mathrm{Pt} / \mathrm{Pd}$ \\
\hline & 2.4 & 0.7 & 3.2 \\
& 2.7 & 1.2 & 2.3 \\
& 1.9 & 0.8 & 2.3 \\
& 3.8 & 1.7 & 2.2 \\
& 3.5 & 0.7 & 4.8 \\
& 4.3 & 2.5 & 1.7 \\
\hline Mean & 3.1 & 1.3 & 2.8 \\
\hline Standard dev. & 0.9 & 0.7 & 1.1 \\
\hline
\end{tabular}

\subsection{Conclusion}

This experiment revealed the ability of Scleropodium purum to be used as an active biomonitor of PGE emissions, and more generally, the ability of mosses to accumulate PGE via dust deposition during active biomonitoring experiments. The advantage of active versus passive biomonitoring is to reduce the sample-to-sample variability and to allow an exposure on the best conditions, theoretically. The moss accumulation behaviour against some parameters has to be explored. The temporal variability of the accumulation and the effect of rain on content must be checked before undertaking large scale active biomonitoring for PGE with mosses. 


\section{References}

Amblard-Gross G, Férard J-F, Carrot F, Maul A, Ducruet J-M, Coddeville P, Béguinel P, Ayrault S (2002) Biological fluxes conversion and SXRF experiment with a new biomonitoring tool for atmospheric metals and trace element deposition. Environ Poll 120: 47-58

Amosse J, Delbos V (2002) Dispersion of Pt, Pd and Rh produced by catalytic converters into the roadside and urban environment: element speciation study. CR Chimie 5(8-9): 565-570

Alt F, Eschnauer H R, Mergler B, Messerschmidt J, Tölg G (1997) A contribution to the ecology and enology of platinum. Fresenius J Anal Chem 357: 10131019

Barbante C, Veyssere A, Ferrari C, Van de Velde K, Morel C, Capodaglio G, Scarponi G, Boutron C (2001) Greenland snow evidence of large scale atmospheric contamination for platinum, palladium and rhodium. Environ Sci Technol 35: 835-839

Dietl C, Laschka D, Wäber M, Peichl L (2000) Biomonitoring of platinum immissions from motor vehicles. In: Zerieini F, Alt F (eds) Anthropogenic Platinum-Group Element Emissions, Their Impact on Man and Environment, Springer, Berlin, pp 65-71

Djingova R, Kovacheva P, Wagner G, Markert B (2003) Distribution of platinum group elements and other traffic related elements among different plants along some highways in Germany. Sci Total Environ 308: 235-246

Ely JC, Neal CR, Kulpa CF, Scheegurt MA, Seidler JA, Jain JC (2001) Implications of platinum-group elements accumulation along U.S. roads from catalytic converter attrition. Environ Sci Technol 35: 3816-3822

Farago M, Kavanagh P, Blanks R, Kelly J, Kazantzis G, Thornton I, Simpson P Cook J, Delves T, Hall G (1998) Platinum concentrations in urban road dust and soil, and in blood and urine in the nited Kingdom. Analyst 123: 451-454

Helmers E, Mergel N (1998) Platinum and rhodium in a polluted environment: studying the emissions of automobile catalysts with emphasis on the application of CSV rhodium analysis. Fresenius J Anal Chem 362: 522-528

Lustig S (1997) Platinum in the environment, UTZ Verlag, Munchen/Germany

Lustig S, Zang S, Michalke B, Schramel P, Beck W (1997) Platinum determination in nutrient plants by inductively coupled plasma mass spectrometry with special respect to hafnium oxide interference. Fresenius J Anal Chem 357: 1157-1163

Lustig S, Schramel P (2000) Platinum bioaccumulation in plants and overview of the situation for palladium and rhodium. In: Zerieini F, Alt F (eds) Anthropogenic Platinum-Group Element Emissions, Their Impact on Man and Environment, Springer, Berlin, pp 95-104

Niemelä M, Perämäki P, Piispann J, Poikolainen J (2004) Determination of platinum and rhodium in dust and plant samples using mpicrowave-assisted sample digestion and ICP-MS. Anal Chim Acta 521: 137-142 
Ravindra K, Bencs L, Van Grieken R (2004) Platinum group elements in the environment and their health risk. Sci Total Environ 318, 1-43

Schäfer J, Hannker D, Eckhardt JD, Stüben D (1998) Uptake of traffic-related heavy metals and platinum group elements (PGE) by plants. Sci Total Environ 215:59-314

Steinnes E (1995) A critical evaluation of the use of naturally growing moss to monitor the deposition of atmospheric metals. Sci Tot Environ 160/161: 243249

Vanhaecke F, Resano M, Pruneda-Lopez M, Moens L (2002) Determination of platinum and rhodium in environmental matrixes by solid samplingelectrothermal vaporization-inductively coupled plasma mass spectrometry. Anal Chem 74, 6040-6048

Wedepohl KH (1995) The composition of the continental crust. Geochim Cosmo Acta 59: 1217-1232

Zereini F, Skerstupp B, Alt F, Helmers E, Urban H (1997) Geochemical behaviour of platinum group metals (PGE) in particulate emissions by automobile catalysts: experimental results and environmental investigations. Sci Tot Environ 206: 137-143 